\title{
ANIMAL GENETIC RESOURCES INFORMATION
}

\section{BULLETIN \\ D'INFORMATION \\ SUR LE RESSOURCES GÉNÉTIQUES ANI MALES}

BOLETIN

DE INFORMACION SOBRE RECURSOS GENETICOS ANIMALES
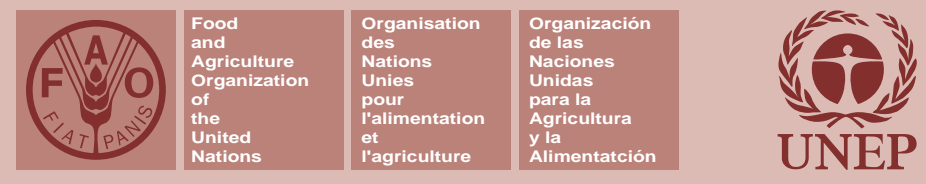

\section{8}

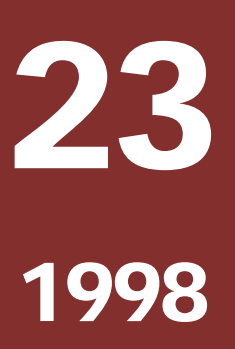


The designations employed and the presentation of material in this publication do not imply the expression of any opinion whatsoever on the part of the Food and Agricultural Organization of the United Nations concerning the legal status of any country, territory, city or area or of its authorities, or concerning the delimitation of its frontiers or boundaries

Les appellations employées dans cette publication et la présentation des données qui y figurent n'impliquent de la part de l'Organisation des Nations Unies pour l'alimentation et l'agriculture aucune prise de position quant au statut juridique des pays, territoires, villes ou zones, ou de leurs autorités, ni quant au tracé de leurs frontières ou limites.

Las denominaciones empleadas en esta publicación y la forma en que aparecen presentados los datos que contiene no implican de parte de la Organización de las Naciones Unidas para la Agricultura y la Alimentación juicio alguno sobre la condición jurídica de países, territorios, ciudades o zonas, o de sus autoridades, ni respecto de la delimitación de sus fronteras o límites.

All rights reserved. No part of this publication may be reproduced, stored in a retrieval system, or transmitted in any form or by any means, electronic, mechanical, photocopying or otherwise, without the prior permission of the copyright owner. Applications for such permission, with a statement of the purpose and the extent of the reproduction, should be addressed to the Director, Information Division, Food and Agriculture of the United Nations, Viale delle Terme di Caracalla, 00100 Rome, Italy.

Tous droits réservés. Aucune partie de cette publication ne peut être reproduite, mise en mémoire dans un système de recherche bibliographique ni transmise sous quelque forme ou par quelque procédé que ce soit: électronique, mécanique, par photocopie ou autre, sans autorisation préalable. Adresser une demande motivée au Directeur de la Division des information, Organisation des Nations Unies pour l'alimentation et l'agriculture, Viale delle Terme di Caracalla, 00100 Rome, Italie, en indiquant les passages ou illustrations en cause.

Reservados todos los derechos. No se podrá reproducir ninguna parte de esta publicación, ni almacenarla en ningún sistema de recuperación de datos o transmitirla en cualquier forma o por cualquier procedimiento (electrónico, mecánico, fotocopia, etc.), sin autorización previa del titular de los derechos de autor. Las peticiones para obtener tal autorización, especificando la extensión de lo que se desea reproducir y el propósito que con ello se persigue, deberán enviarse al Director de la División de Información, Organización de las Naciones Unidas para la Agricultura y la Alimentación, Viale delle Terme di Caracalla, 00100 Roma, Italia.

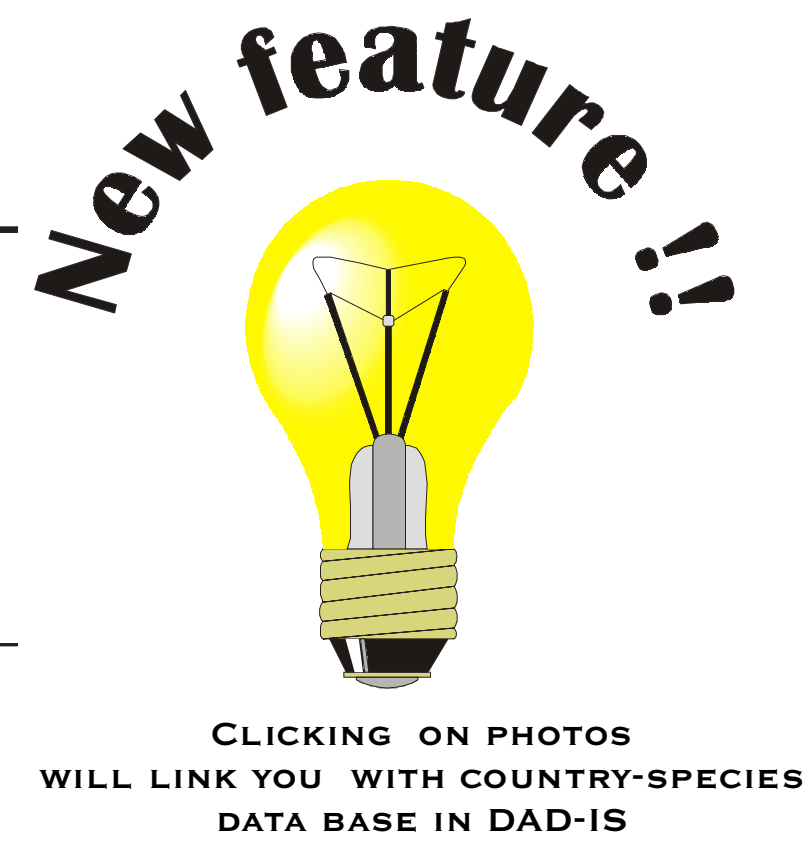


Editors - Editeurs - Editores:

S. Galal \& J. Boyazoglu

Viale delle Terme di Caracalla 1, 00100 Rome, Italy

Animal Genetic Resources Information is published under the joint auspices of the Food and Agriculture Organization of the United Nations (FAO) and the United Nations Environment Programme (UNEP). It is edited in the Animal Genetic Resources Group of the Animal Production and Health Division of FAO. It is available direct from FAO or through the usual FAO sales agents.

ANIMAL GENETIC RESOURCES INFORMATION will be sent free of charge to those concerned with the sustainable development conservation of domestic livestock. Anyone wishing to receive it regularly should send their name and address to the Editor, at the address shown above.

AGRI can also be found in the "Library" of DAD-IS at URL http//www.fao.org/dad-is.

Le Bulletin d'information sur les ressources génétiques animales est publié sous les auspices conjoints de l'Organisation des Nations Unies pour 1'Alimentation et l'Agriculture (FAO) et du Programme des Nations Unies pour l'Environnement (UNEP). Cette publication est éditée par le Groupe des Ressources Génétiques de la Division de la Production et de la Santé Animales de la FAO. On peut se le procurer directement au siège de la FAO ou auprès des dépositaires et agents habituels de vente de publication de l'Organisation.

LE BULLETIN D'INFORMATION SUR LES RESSOURCES GÉNÉTIQUES ANIMALES sera envoyé gratuitement aux personnes intéressées par le développement durable et la conservation du bétail domestique. Les personnes souhaitant recevoir cette publication régulièrement voudront bien faire parvenir leurs nom et adresse à l'éditeur, à l'adresse sus-indiquée.

AGRI peut être consulté également sur la "Librairie" de DAD-IS de URL http//www.fao.org/ dad-is.

El Boletín de Información sobre Recursos Genéticos Animales se publica bajo les auspicios de la Organización de las Naciones Unidas para la Agricultura y la Alimentación (FAO) y del Programa de la Naciones Unidas para el Medio Ambiente (UNEP). Se edita en el Grupo de Recursos Genéticos de la Dirección de Producción y Sanidad Animal de la FAO. Se puede obtener directamente de la FAO o a través de sus agentes de venta habituales.

El BOLETIN DE INFORMACION SOBRE RECURSOS GENETICOS ANIMALES será enviado gratuitamente a quienes estén interesados en el desarrollo sostenible y la conservación del ganado doméstico. Si se desea recibirlo regularmente, se ruega comunicar nombre, apellido y dirección al editor a la dirección arriba indicada. AGRI puede consultarse también en la "Librería" de DAD-IS de URL http// www.fao.org/dad-is.
ANIMAL GENETIC

RESOURCES INFORMATION

BULLETIN

D'INFORMATION SUR LES

RESSOURCES GENETIQUES

ANIMALES

Boletin DE

INFORMACION SOBRE RECURSOS

GENETICOS ANIMALES

CONTENTS

Page

Editorial

Genetic of disease resistance in Bos taurus cattle

\section{C.A. Morris}

Indigenous cattle of Zanzibar: the need for conservation

K.O. Ali

The use of DNA markers in deciding conservation priorities

in sheep and other livestock

A.M. Crawford \& R.P. Littlejohn

The development and maintenance of animal recording systems in Greece: a case study

A. Georgoudis \& A. Baltas

Caballo Chilote

A. Escobar, J. Oltra, M. Ortiz \& J. Voeltz

Review of global rabbit genetic resources: special emphasis

on breeding programs and practices in the lesser developed countries

S. D. Lukefahr

Indigenous domestic turkeys of Oaxaca and Quintana Roo, Mexico

J.G. Mallia

Recent publications

Editorial policies and procedures

91

Food and Agriculture Organization of the United Nations Organisation des Nations Unies POUR L'Alimentation et l'Agriculture Organizacion de las Naciones Unidas para la Agricultura y la Alimentacion

United Nations Environment Programme Programme des Nations Unies pour L'Environnement Programa de las Naciones Unidas para el Medio Ambiente 